\title{
The importance of HDL-C and CRP in cardiovascular risk evaluation in longevous elderly individuals
}

\author{
A importância do HDL-C e da PCR na avaliação do risco cardiovascular em idosos longevos
}

\author{
Renato Laks ${ }^{1}$, Lara Miguel Quirino Araújo ${ }^{1}$, Clineu de Mello Almada Filho ${ }^{1}$, Maysa Seabra Cendoroglo ${ }^{1}$
}

\begin{abstract}
The association between total mortality, lipoproteinS, and inflammatory markers, and their implications with aging and longevity are often controversial. Among the most often studied markers are low HDL cholesterol and high C-reactive protein. Particularly in octogenarians, it is expected that the impact of the inclusion of HDL cholesterol and C-reactive protein will improve the stratification of absolute cardiovascular risk. In the present study, we performed a literature review in PubMed about the relation between HDL cholesterol, inflammation and longevity. Applying the inclusion and exclusion criteria adopted, we selected 30 studies, among which one systematic review on the relation between HDL cholesterol and stroke, one metaanalysis on the relation between total cholesterol and HDL cholesterol with mortality, 22 longitudinal studies, and six cross-sectional studies. The results show an inverse association between HDL cholesterol and total mortality, and between cardiovascular mortality and C-reactive protein, as well as a positive association between $\mathrm{C}$-reactive protein and mortality in longevous individuals. C-reactive protein and HDL cholesterol displayed promising characteristics as predictors of cardiovascular mortality in longevous elderly persons.
\end{abstract}

Keywords: Longevity; C-reactive protein; Lipoproteins, HDL; Cholesterol, HDL; Mortality; Cardiovascular system; Lipids

\section{RESUMO}

A associação entre mortalidade total, lipoproteínas e marcadores inflamatórios, e suas implicações com o envelhecimento e a longevidade são, muitas vezes, controversas. Entre os marcadores mais estudados, encontram-se o colesterol HDL baixo e a proteína C-reativa alta. Particularmente, nos octogenários, espera-se que o impacto da inclusão do colesterol HDL e da proteína C-reativa melhore a estratificação do risco cardiovascular absoluto. No presente trabalho, realizamos uma revisão da literatura por meio do PubMed sobre a relação entre colesterol HDL, inflamação e longevidade. Aplicando os critérios de inclusão e exclusão adotados, selecionamos 30 estudos, dentre os quais 1 revisão sistemática sobre a relação entre colesterol HDL e acidente vascular cerebral, 1 meta-análise sobre a relação entre colesterol total e colesterol HDL com mortalidade, 22 estudos longitudinais e 6 estudos transversais.
Os resultados mostram uma associação inversa entre o colesterol HDL e a mortalidade total, e entre a mortalidade cardiovascular e a proteína C-reativa, assim como uma associação positiva entre a proteína C-reativa e a mortalidade em longevos. A proteína C-reativa e o colesterol HDL apresentam características promissoras como preditores de mortalidade cardiovascular em idosos longevos.

Descritores: Longevidade; Proteína C-reativa; Lipoproteínas HDL; Colesterol HDL; Mortalidade; Sistema cardiovascular; Lipídeos

\section{INTRODUCTION}

The prevalence of atherosclerotic cardiovascular disease increases exponentially with aging, and it is the main cause of morbidity and mortality in the aged. Risk stratification is fundamental for determining treatment goals. However, the predictive value of traditional risk factors decreases with age, while the identification of emerging risk markers shows greater importance, primarily for longevous elderly people.

Elevated levels of C-reactive protein (CRP) are a well-established biomarker in middle-aged adults. Albert et al., in a cross-sectional study conducted in 2003, showed a significant correlation between the levels of CRP and Framingham risk score ${ }^{(1)}$.

In a prospective study, Danesh et al. ${ }^{(2)}$ investigated the relation between CRP and coronary artery disease (CAD) in 2459 participants that developed coronary artery disease (CAD) and 3969 controls. The mean age was 56 years, and the odds ratio to develop CAD fell between the terciles with the greatest and lowest CRP levels ( $>2 \mathrm{mg} / \mathrm{L}$ and $<0.78 \mathrm{mg} / \mathrm{L}$, respectively) of 1.45 (CI95\%: 1.25-1.68). These authors also conducted a meta-analysis with the same objectives, involving 22 prospective studies and 7068 participants, resulting in an odds ratio for the development of CAD in the elevated CRP group of 1.58 (CI95\%: 1.48-1.68). The Emerging Risk Factors Collaboration carried out

\footnotetext{
'Department of Geriatrics and Gerontology, Escola Paulista de Medicina, Universidade Federal de São Paulo - UNIFESP, Sao Paulo (SP), Brazil.

Corresponding author: Renato Laks - Rua Comendador Miguel Calfat, 128, Conjunto 308 - Itaim Bibi - CEP 04537-080- Sao Paulo (SP), Brazil - Tel.: (11) 3846-2462 - E-mail: renatolaks@yahoo.com

Received on: Dec 22, 2010 - Accepted on: Sep 2, 2011.
} 
a new meta-analysis in 2010 involving 54 prospective studies, with 160 thousand participants at a mean age of 60 years, and obtained a relative risk of 1.55 with an increase of one standard deviation in the CRP concentration $\log ^{(3)}$.

We can also highlight the importance of the intervention study "Justification for the Use of Statins in Prevention: an Intervention Trial Evaluating Rosuvastatin" - JUPITER, which demonstrated that treatment of inflammation, evaluated by means of CRP, was effective regardless of the LDL cholesterol (LDL-C) target. This clinical trial enrolled 17802 individuals, with a mean age of 66 years and average follow-up of 1.9 years, with LDL-C $<130 \mathrm{mg} / \mathrm{dL}$ and CRP $>2 \mathrm{mg} / \mathrm{L}$, assessing the benefit of introducing rosuvastatin. The group that used the medication showed a reduction by $37 \%$ in CRP levels, with a relative risk for cardiovascular mortality or cardiovascular events $>0.56(\mathrm{p}<0.00001)^{(4,5)}$.

The relation between low HDL cholesterol (HDL-C) and cardiovascular risk is also well established in middle-aged adults. Gordon et al. evaluated the data of four large prospective American studies, resulting in 15252 participants, aged between 30 and 69 years, and obtained a significant protective relation between HDL-C and CAD. The increase by $1 \mathrm{mg} / \mathrm{dL}$ of HDL-C resulted in a CAD reduction by approximately $2 \%$ and $3 \%$ in men and women, respectively ${ }^{(6)}$.

Cooney et al. investigated the impact of the inclusion of HDL-C in the cardiovascular risk stratification of 104,961 adults at 47 years of age, from 12 European cohorts that originated the Systematic Coronary Risk Evaluation (SCORE), showing a statistically significant improvement of the index of risk reclassification, with a relative risk of 0.62 and 0.76 in women and men, respectively, and a slight modification of the absolute risk $(6.5 \%$ of the participants increased risk by $1 \%)^{(7)}$. The same authors, in another study published in 2009, evaluated the effect of HDL-C in cardiovascular morbidity and mortality also by means of the SCORE study cohorts; this time, however, the age group of over 65 years was included. In these, an increase of $19.3 \mathrm{mg} / \mathrm{dL}$ resulted in a relative risk of 0.53 (CI95\%: 0.42-0.8) and 0.79 (CI95\%: 0.64-0.98) for women and men, respectively. These data become even more relevant because in longevous elderly relative risks are frequently attenuated, since age is an important risk factor, but reductions in absolute risk are generally greater, due to the high prevalence of cardiovascular diseases ${ }^{(8)}$.

Nevertheless, in a systematic review performed in 2008, including 108 clinical trials, Briel et al. obtained no additional benefit with increased HDL-C relative to the isolated reduction of LDL-C, indicating that in middle-aged adults, possibly HDL-C fractions are more important than their total value ${ }^{(9)}$. In another prospective study with 89 adult individuals, CRP (24\% presented with levels $>3 \mathrm{mg} / \mathrm{dL}$ ) and low HDL-C (72\% prevalence) were more prevalent and essential predictors compared to traditional risk factors in individuals with familial history of coronary disease ${ }^{(10)}$

Particularly in octogenarians, it is expected that the inclusion of HDL-C and CRP improve the absolute cardiovascular risk stratification. Therefore, the objective of this study was to investigate in literature data on the association between total mortality, lipoproteins, and inflammatory markers, and their implications with aging and longevity.

\section{METHODS}

This was a study of an exploratory and descriptive nature, based on the qualitative method of investigation.

We performed a search in PubMed, of the National Library of Medicine (http://www.ncbi.nlm.nih.gov/ pubmed) combining the following $\mathrm{MeSH}$ (medical subject headings) descriptors: "lipids", "C-reactive protein", "lipoproteins, "HDL", "mortality", and "cardiovascular system". The investigation considered articles published from January 2003 to August 15, 2010.

Next, we applied the following inclusion criteria:

- systematic reviews;

- observational studies (cohort, cross-sectional, casecontrol, and ecological studies);

- languages: English, Portuguese, and Spanish;

- inclusion of individuals aged over 80 years.

The exclusion criteria were:

- specific population studies (for example, patients undergoing hemodialysis), due to the difficulty of applying data to the general population.

Based on the selection of studies that met these criteria, we initiated the detailed analysis, as per the level of evidence.

\section{RESULTS}

Using the PubMed search strategy, 2617 studies of potential relevance were identified for the combination of descriptors "C-reactive protein" and "lipids"; 519 publications combining the terms "lipoproteins, HDL" and "C-reactive protein"; 750 with the terms "lipoproteins, HDL" and "cardiovascular system"; 1191 combining "lipids" and "mortality"; 60 with "lipoproteins, HDL" and "mortality"; 290 with "C-reactive protein" and "mortality", and 1423 with the combination of "C-reactive protein" and "cardiovascular system". 
Applying the inclusion and exclusion criteria adopted, we selected 30 studies, in which one was a systematic review on the relation between HDL-C and cerebrovascular accidents ${ }^{(11)}$, one meta-analysis on the relation between total cholesterol and HDL-C with mortality ${ }^{(12)}, 22$ longitudinal studies, and 6 crosssectional studies ${ }^{(13-40)}$. The description of these articles is displayed in chart 1 .

Chart 1. Articles which analysed the importance of HDL-C and CRP in cardiovascular risk evaluation in longevous elderly individuals

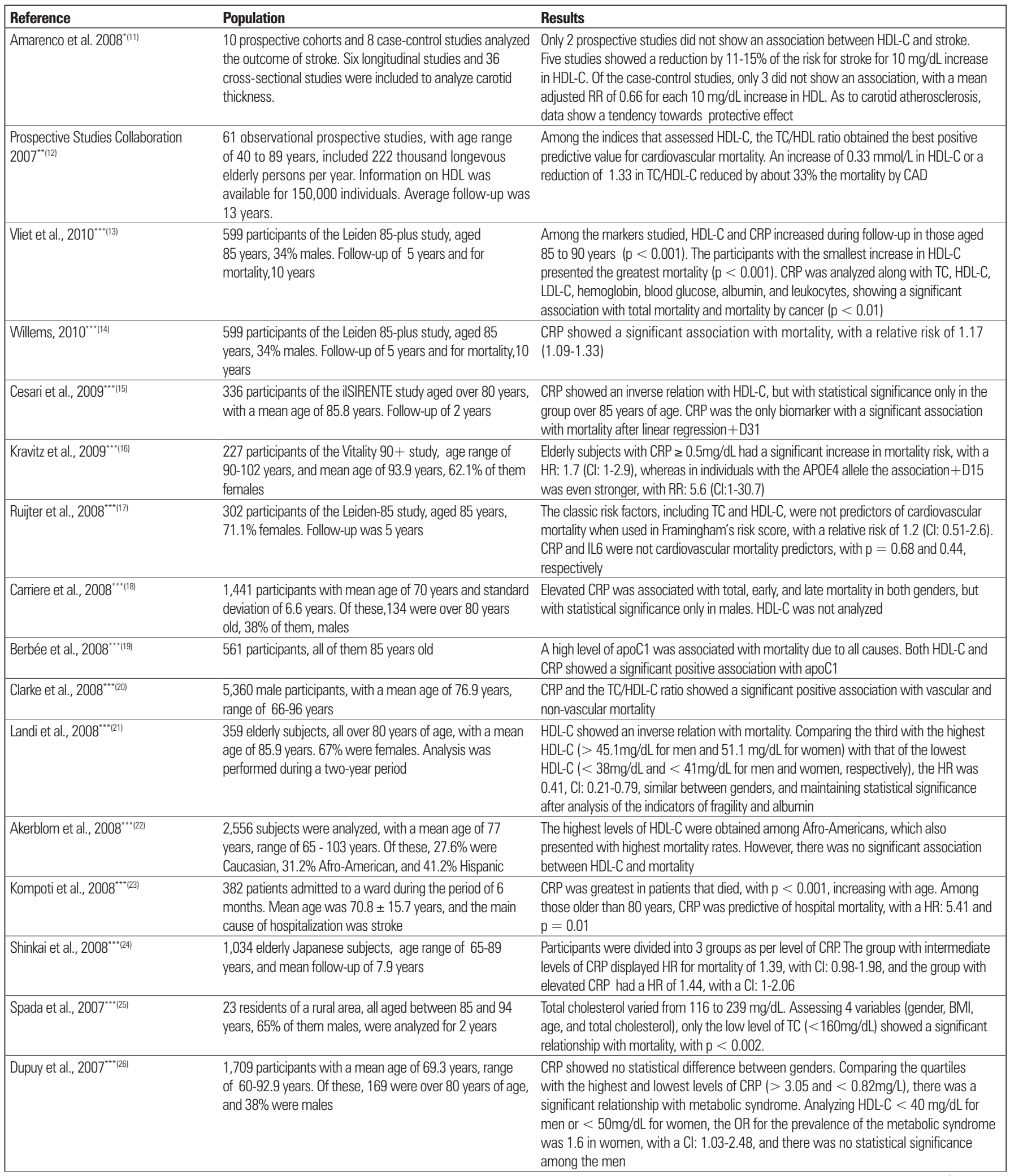


...Continuation

Chart 1. Articles which analysed the importance of HDL-C and CRP in cardiovascular risk evaluation in longevous elderly individuals

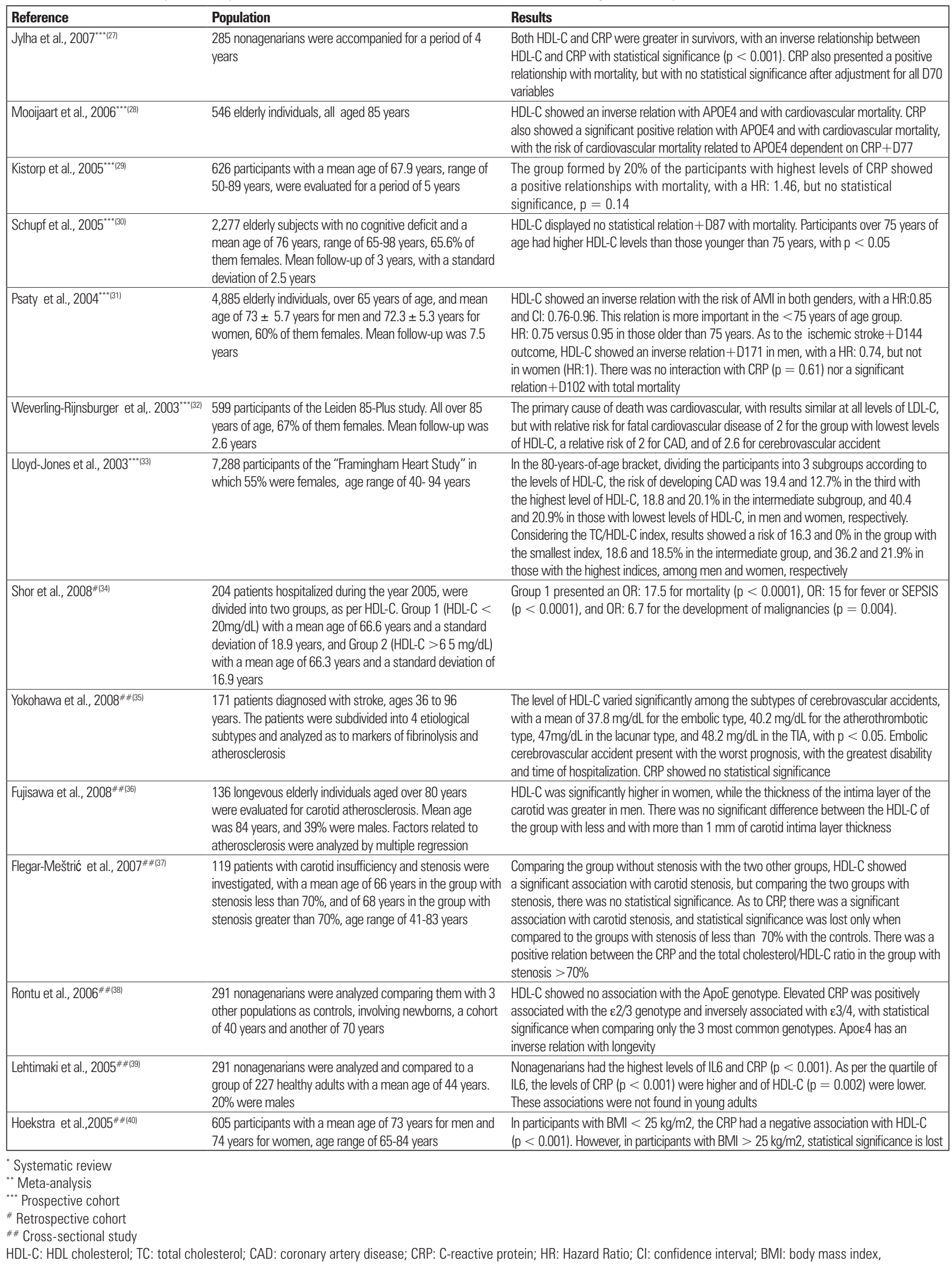




\section{DISCUSSION}

The objective of this review was to investigate in literature the studies that assess the relation between HDL-C, CRP, and longevity. We found a relatively small number of studies, and most of them show a strong association between low levels of HDL-C and high CRP with cardiovascular morbidity and mortality in this age group.

Data from the "Cardiovascular Health Study", which included only individuals over 65 years of age, with a mean age of 72 years, showed that approximately $50 \%$ of women and $60 \%$ of men without clinical cardiovascular disease presented with subclinical disease, defined by alterations in the echocardiogram or electrocardiogram, carotid thickness or carotid stenosis upon Doppler ultrasound, and decreased ankle-brachial index ${ }^{(41)}$. In this way, the subclinical presentation of the disease and the factors that accelerate its progression or destabilize atherosclerotic disease seem to have greater relevance than atherogenic factors for this age group. HDL-C and CRP present different properties that influence the stability of plaque. HDL-C participates in the reverse transport of cholesterol and also presents antioxidant properties that are antioxidant, anti-inflammatory and antithrombotic, besides contributing to endothelial damage ${ }^{(42)}$. CRP sustains a status that is prothrombotic, proinflammatory and proatherosclerotic by means of its effects in regulation of endothelial cells, in vascular remodeling, in macrophage function, in increased migration, proliferation and production of oxygen free radicals by smooth muscle cells of blood vessels and in the increased activity of metalloproteinases, with resulting degradation of the biological matrix and instability of the atherosclerotic plaque ${ }^{(43)}$.

Weverling-Rijnsburger et al. ${ }^{(32)}$, in a study involving 599 elderly persons, all aged over 85 years, showed a relative risk of 2 for cardiovascular mortality in the group with the lowest levels of HDL-C, in which the cardiovascular mortality was independent of the levels of LDL-C. Ruijter et al. ${ }^{(17)}$ studied the same cohort of aged individuals with more than 85 years of age, but they excluded participants with past history of cardiovascular disease, resulting in 302 aged subjects. In these, the level of HDL-C was not a predictor of cardiovascular risk. However, in excluding the patients with heart diseases, also excluded were patients with lower levels of HDL-C, as HDL-C was around 42 to $62 \mathrm{mg} / \mathrm{dL}$, with a mean of $50.2 \mathrm{mg} / \mathrm{dL}$, while the tercile with the lowest HDL-C of the initial cohort showed values between 32 and $40 \mathrm{mg} / \mathrm{dL}$.

The Prospective Studies Collaboration ${ }^{(12)}$ analyzed the relation between mortality and lipid profile by means of a meta-analysis of 61 prospective studies involving
900 thousand subjects, aged between 40 and 89 years, showing a $33 \%$ reduction in mortality by CAD with the increase of $12 \mathrm{mg} / \mathrm{dL}$ of HDL-C ${ }^{(12)}$. In this study, total cholesterol lost statistical significance to predict cerebrovascular accidents and vascular mortality in very old individuals, except for $\mathrm{CAD}$, concluding that HDL-C was a more significant predictor for mortality than LDL-C and total cholesterol in longevous elderly individuals.

HDL-C is classified by its size and density into two primary fractions: HDL2-C, larger and rich in cholesterol, and HDL3-C, smaller and with less cholesterol. It is likely that HDL2-C is the fraction that best represents the reverse transport of cholesterol, and when its levels are low, there is an association with high cardiovascular risk. Ettinger et al., in a cross-sectional study in 1952 elderly persons over 65 years of age, showed that the higher HDL-C with aging probably is due to the increased fraction of HDL2- ${ }^{(44)}$.

The relation between high CRP and vascular and non-vascular mortality suggests that the CRP gene is possibly one of those related to longevity ${ }^{(45)}$ Polymorphisms of the CRP gene are associated with the increase in its serum level. However, the association between these polymorphisms and increased mortality has not been established yet ${ }^{(46)}$. On the other hand, Mooijaart et al. ${ }^{(28)}$, in a cohort of longevous elderly people, showed that the apolipoprotein $\mathrm{E}$ gene is associated with lower HDL-C, higher levels of CRP, and increased mortality, and this effect on mortality is dependent on CRP levels.

The present study showed that in longevous aged, low levels of HDL-C are better predictors of cardiovascular mortality that the other cholesterol fractions, possibly substituting LDL-C as the main goal of treatment in this age group. Nevertheless, before altering the goals of prevention, more clinical trials are needed with the objective of increasing HDL-C in the population over 80 years of age.

A high level of CRP also proved an excellent predictor of cardiovascular mortality in longevous elderly individuals. On the other hand, despite the JUPITER study having shown benefits in its reduction with rosuvastatin, there is also a need for more clinical trials that include longevous individuals.

The identification of biological markers of longevity willenable the development of studies on the mechanisms that protect humans from common diseases and delay biological aging processes. Ideally, cardiovascular risk markers should provide prognostic information on various levels of risk, adding information to the traditional risk factors, and should be reproducible, with accessible costs and high prevalence in the population evaluated. 


\section{CONCLUSION}

CRP and HDL-C present promising characteristics, although they still require greater evidence. Future research should explore the relations between them and cardiovascular disease in longevous elderly population, collaborating with their incorporation into traditional risk factors in the preparation of guidelines for this growing age group, which is still insufficiently studied.

\section{ACKNOWLEDGMENTS}

\section{We thank Gabriel Seabra Cendoroglo for his collaboration in this project.}

\section{REFERENCES}

1. Albert MA, Glynn RJ, Ridker PM. Plasma concentration of C-reactive protein and the calculated Framingham coronary heart disease risk score. Circulation. 2003;108(2):161-5.

2. Danesh J, Wheeler JG, Hirschfield GM, Eda S, Eiriksdottir G, Rumley A, et al. C-reactive protein and other circulating markers of inflammation in the prediction of coronary heart disease. N Engl J Med. 2004;350(14):1387-97.

3. Emerging Risk Factors Collaboration, Kaptoge S, Di Angelantonio E, Lowe G, Pepys MB, Thompson SG, Collins R, Danesh J. C-reactive protein concentration and risk of coronary heart disease, stroke, and mortality: an individual participant meta-analysis. Lancet. 2010;375(9709):132-40.

4. Ridker PM, Danielson E, Fonseca FA, Genest J, Gotto AM Jr, Kastelein JJ et al Nordestgaard BG, Shepherd J, Willerson JT, Glynn RJ; JUPITER Study Group. Rosuvastatin to prevent vascular events in men and women with elevated C-reactive protein. N Engl J Med. 2008;359(21):2195-207.

5. Glynn RJ, Koenig W, Nordestgaard BG, Shepherd J, Ridker PM. Rosuvastatin for primary prevention in older persons with elevated C-reactive protein and low to average low-density lipoprotein cholesterol levels: exploratory analysis of a randomized trial. Ann Intern Med. 2010;152(8):488-96, W174.

6. Gordon DJ, Probstfield JL, Garrison RJ, Neaton JD, Castelli WP, Knoke JD, et al. High-Density lipoprotein cholesterol and cardiovascular disease. Four prospective American studies. Circulation. 1989;79(1):8-15.

7. Cooney MT, Dudina A, Bacquer DD, Fitzgerald A, Conroy R, Sans S, Menotti A, De Backer G, Jousilahti P, Keil U, Thomsen T, Whincup P, Graham I, SCORE Investigators. How much does HDL cholesterol add to risk estimation? A report from the SCORE investigators. Eur J Cardiovasc Prev Rehabil. 2009;16(3): 304-14.

8. Upmeier E, Lavonius S, Lehtonen A, Viitanen M, Isoaho H, Arve S. Serum lipids and their association with mortality in the elderly: a prospective cohort study. Aging Clin Exp Res. 2009;21(6):424-430.

9. Briel M, Ferreira-Gonzalez I, You JJ, Karanicolas PJ, Akl EA, Wu P, et al. Association between change in high density lipoprotein cholesterol and cardiovascular disease morbidity and mortality: systematic review and metaregression analysis. BMJ. 2009;338:b92.

10. Sailam V, Karalis DG, Agarwal A, Alani F, Galardi S, Covalesky V, et al. Prevalence of emerging cardiovascular risk factors in younger individuals with a family history of premature coronary heart disease and low Framingham risk score. Clin Cardiol. 2008;31(11):542-5.

11. Amarenco P, Labreuche J, Touboul PJ. High-density lipoprotein-cholesterol and risk of stroke and carotid atherosclerosis: A systematic review. Atherosclerosis. 2008;196(2):489-96.

12. Prospective Studies Collaboration, Lewington $S$, Whitlock G, Clarke R, Sherliker P, Emberson J, Halsey J, Qizilbash N, Peto R, Collins R. Blood cholesterol and vascular mortality by age, sex, and blood pressure: a meta-analysis of individual data from 61 prospective studies with 55000 vascular deaths. Lancet. 2007;370(9602):1829-39.

13. van Vliet P, Oleksik AM, van Heemst $D$, de Craen AJ, Westendorp RG Dynamics of traditional metabolic risk factors associate with specific causes of death in old age.J Gerontol A Biol Sci Med Sci. 2010;65(5):488-94.

14. Willems JM, Trompet S, Blauw GJ, Westendorp RG, de Craen AJ. White blood cell count and C-reactive protein are independent predictors of mortality in the oldest old. J Gerontol A Biol Sci Med Sci. 2010;65(7):764-8.

15. Cesari M, Onder G, Zamboni V, Capoluongo E, Russo A, Bernabei R, et al. $\mathrm{C}$-reactive protein and lipid parameters in older persons aged 80 years and older. J Nutr Health Aging. 2009;13(7):587-93.

16. Kravitz BA, Corrada MM, Kawas CH. High levels of serum C-reactive protein are associated with greater risk of all-cause mortality, but not dementia, in the oldest-old: results from The 90+ Study. J Am Geriatr Soc. 2009;57(4):641-6.

17. de Ruijter W, Westendorp RG, Assendelft WJ, den Elzen WP, de Craen AJ, le Cessie $S$, et al. Use of Framingham risk score and new biomarkers to predict cardiovascular mortality in older people: population based observational cohort study. BMJ. 2009;8;338:a3083.

18. Carriere I, Dupuy AM, Lacroux A, Cristol JP, Delcourt C. Pathologies Oculaires Liées à I'Age Study Group Biomarkers of inflammation and malnutrition associated with early death in healthy elderly people. J Am Geriatr Soc. 2008;56(5):840-6.

19. Berbée JFP, Mooijaart SP, Craen AJM, Havekes LM, Heemst D, Rensen PCN, Westerdorn RGJ. Plasma apolipoprotein $\mathrm{Cl}$ protects against mortality from infection in old age. J Gerontol Series A. 2008;63(2):122-6.

20. Clarke R, Emberson JR, Breeze E, Casas JP, Parish S, Hingorani AD, et al. Biomarkers of inflammation predict both vascular and non-vascular mortality in older men. Eur Heart J. 2008;29(6):800-9.

21. Landi F, Russo A, Pahor M, Capoluongo E, Liperoti R, Cesari M, et al. Serum high-density lipoprotein cholesterol levels and mortality in frail, communityliving elderly. Gerontology. 2008;54(2):71-8.

22. Akerblom JL, Costa R, Luchsinger JA, Manly JJ, Tang MX, Lee JH, et al. Relation of plasma lipids to all-cause mortality in caucasian, african-american and hispanic elders. Age Ageing. 2008;37(2):207-13.

23. Kompoti M, Drimis S, Papadaki A, Kotsomytis K, Poulopoulou C, Gianneli D, et al. Serum C-reactive protein at admission predicts in-hospital mortality in medical patients. Eur J Intern Med. 2008;19(4):261-5.

24. Shinkai S, Chaves PH, Fujiwara Y, Watanabe S, Shibata H, Yoshida H, et al. Beta2-microglobulin for risk stratification of total mortality in the elderly population: comparison with cystatin $\mathrm{C}$ and $\mathrm{C}$-reactive protein. Arch Intern Med. 2008;28;168(2):200-6.

25. Spada RS, Toscano G, Cosentino Fl, lero I, Lanuzza B, Tripodi M, et al. Low total cholesterol predicts mortality in the nondemented oldest old. Arch Gerontol Geriatr. 2007;44 Suppl 1:381-4.

26. Dupuy AM, Jaussent I, Lacroux A, Durant R, Cristol JP, Delcourt C. Waist circumference adds to the variance in plasma $C$-reactive protein levels in elderly patients with metabolic syndrome. Gerontology. 2007;53(6):329-39.

27. Jylhä M, Paavilainen P, Lehtimäki T, Goebeler S, Karhunen PJ, Hervonen A, et al. Interleukin-1 receptor antagonist, interleukin-6, and C-reactive protein as predictors of mortality in nonagenarians: the vitality $90+$ study. J Gerontol A Biol Sci Med Sci. 2007;62(9):1016-21

28. Mooijaart SP, van Vliet P, van Heemst D, Rensen PC, Berbée JF, Jolles J, et al. Westendorp RG. Plasma levels of apolipoprotein $E$ and cognitive function in old age. Ann N Y Acad Sci. 2007;1100:148-61

29. Kistorp C, Raymond I, Pedersen F, Gustafsson F, Faber J, Hildebrandt P. $\mathrm{N}$-terminal pro-brain natriuretic peptide, $\mathrm{C}$-reactive protein, and urinary albumin levels as predictors of mortality and cardiovascular events in older adults. JAMA. 2005;293(13):1609-16.

30. Schupf N, Costa R, Luchsinger J, Tang MX, Lee JH, Mayeux R.0. Relationship between plasma lipids and all-cause mortality in nondemented elderly. J Am Geriatr Soc. 2005;53(2):219-26. 
31. Psaty BM, Anderson M, Kronmal RA, Tracy RP, Orchard T, Fried LP, et al. The association between lipid levels and the risks of incident myocardial infarction, stroke, and total mortality: The Cardiovascular Health Study. J Am Geriatr Soc. 2004;52(10):1639-47.

32. Weverling-Rijnsburger AW, Jonkers IJ, van Exel E, Gussekloo J, Westendorp RG. High-density vs low-density lipoprotein cholesterol as the risk factor for coronary artery disease and stroke in old age. Arch Intern Med. 2003;163(13):1549-54.

33. Lloyd-Jones DM, Wilson PW, Larson MG, Leip E, Beiser A, D'Agostino RB, et al. Lifetime risk of coronary heart disease by cholesterol levels at selected ages. Arch Intern Med. 2003;163(16):1966-72.

34. Shor R, Wainstein J, Oz D, Boaz M, Matas Z, Fux A, Halabe A. Low HDL levels and the risk of death, sepsis and malignancy. Clin Res Cardiol. 2008;97(4): 227-33.

35. Yokokawa H, Goto A, Terui K, Funami Y, Watanabe K, Yasumura S. Prevalence of metabolic syndrome and serum marker levels in patients with four subtypes of cerebral infarction in Japan. J Clin Neurosci. 2008;15(7):769-73

36. Fujisawa M, Okumiya K, Matsubayashi K, Hamada T, Endo H, Doi Y. Factors associated with carotid atherosclerosis in community-dwelling oldest elderly aged over 80 years. Geriatr Gerontol Int. 2008;8(1):12-8.

37. Flegar-Mestrić Z, Vrhovski-Hebrang D, Preden-Kereković V, Perkov S, Hebrang $A$, Grga $A$, et al. C-reactive protein level in severe stenosis of cerebral arteries. Cerebrovasc Dis. 2007;23(5-6):430-4.

38. Rontu R, Ojala P, Hervonen A, Goebeler S, Karhunen PJ, Nikkilä M, et al. T. Apolipoprotein $\mathrm{E}$ genotype is related to plasma levels of $\mathrm{C}$-reactive protein and lipids and to longevity in nonagenarians. Clin Endocrinol (0xf). 2006;64(3):265-70.

39. Lehtimäki T, Ojala P, Rontu R, Goebeler $S$, Karhunen PJ, Jylhä M, et al. - Interleukin-6 modulates plasma cholesterol and C-reactive protein concentrations in nonagenarians. J Am Geriatr Soc. 2005;53(9):1552-8.

40. Hoekstra T, Geleijnse JM, Schouten EG, KokFJ, KluftC. Relationship ofC-reactive protein with components of the metabolic syndrome in normal-weight and overweight elderly. Nutr Metab Cardiovasc Dis. 2005;15(4):270-8.

41. Mukamal KJ, Kronmal RA, Tracy RP, Cushman M, Siscovick DS. Traditional and novel risk factors in older adults: cardiovascular risk assessment late in life. Am J Geriatr Cardiol. 2004;13(2):69-80.

42. Rye K, Barter PJ, Anti-inflammatory Actions of HDL: A new insight. Arterioscler Thromb Vasc Biol. 2008;28(11):1890-1.

43. Verma $S$, Devaraj $S$, Jialal I. Is C-reactive protein an innocent bystander or proatherogenic culprit? C-Reactive protein promotes atherothrombosis. Circulation. 2006;113(17):2128-51.

44. Ettinger Jr WH, Verdery RB, Wahl PW, Fried LP, High density lipoprotein cholesterol subfractions in older people. J Gerontol. 1994;49(3):M116-M122.

45. Hindorff LA, Rice KM, Lange LA, Diehr P, Halder I, Walston J, et al. Common variants in the CRP gene in relation to longevity and cause-specific mortality in older adults: the Cardiovascular Health Study. Atherosclerosis. 2008;197(2):922-30.

46. Zacho J, Tybjærg-Hansen A, Jensen JS, Grande P, Sillesen H, Nordestgaard BG. Genetically elevated C-reactive protein and ischemic vascular disease. N Engl J Med. 2008;359(18):1897-908. 